AperTO - Archivio Istituzionale Open Access dell'Università di Torino

\title{
White Certificates in the Italian Energy Oligopoly Market
}

\section{This is the author's manuscript}

Original Citation:

Availability:

This version is available http://hdl.handle.net/2318/138039

since 2017-05-25T13:49:57Z

Published version:

DOI:10.1080/15567240902839286

Terms of use:

Open Access

Anyone can freely access the full text of works made available as "Open Access". Works made available under a Creative Commons license can be used according to the terms and conditions of said license. Use of all other works requires consent of the right holder (author or publisher) if not exempted from copyright protection by the applicable law. 


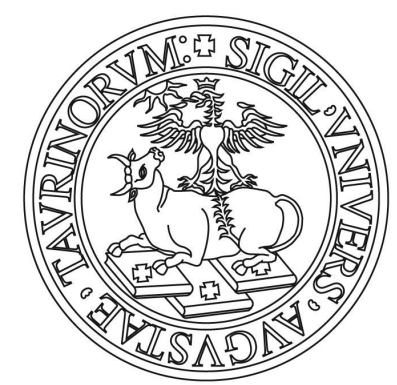

\section{UNIVERSITÀ DEGLI STUDI DI TORINO}

This is an author version of the contribution published on:

Questa è la versione dell'autore dell'opera:

V. Oikonomou, M. Di Giacomo, D. Russolillo, F. Becchis. White

Certificates in the Italian Energy Oligopoly Market,

Energy Sources, Part B: Economics, Planning, and Policy

Vol. 7, Iss. 1, 2012

DOI: $10.1080 / 15567240902839286$

The definitive version is available at:

La versione definitiva è disponibile alla URL:

http://www.tandfonline.com/doi/full/10.1080/15567240902839286\#.UxnE oc4ynuw 


\title{
White Certificates in the Italian energy oligopoly market
}

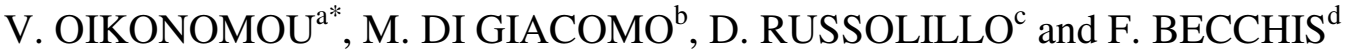 \\ ${ }^{a}$ SOM, University of Groningen, PO Box 800, 9700 AV Groningen, The Netherlands \\ ${ }^{b}$ University of Torino, Dipartimento di Scienze Economiche e Finanziarie, Corso \\ Unione Sovietica 218 bis, 10134 Torino, Italy \\ 'Fondazione per l' Ambiente 'T. Fenoglio', Via Pomba 23, 10123, Torino, Italy \\ ${ }^{d}$ University of East Piedmont, POLIS Department, Alessandria, Novara, Italy \\ *Corresponding author: email:v.oikonomou@rug.nl
}

\begin{abstract}
In this paper we deviate from neoclassical assumptions of fully competitive energy markets, and represent a more realistic oligopolistic market, given the reconsolidation tendencies of energy companies. We focus on policies for energy efficiency improvement for electricity suppliers, namely on White Certificates. The behaviour of each supplier is based on a detailed decision tree, which determines the optimal move given the expectation on the competitor's behaviour. According to our preliminary findings, the introduction of white certificate obligations should encompass larger increases in the electricity prices. In order to test our theoretical findings we make use of a typical oligopolistic market in Italy, where we depict that a leader company can serve the main part of electricity and energy efficiency projects, through financing them with White Certificates, while the residual demand is more expensive and must be covered at a high cost from follower companies.
\end{abstract}

Keywords: White Certificates, oligopoly models, electricity supply, Stackelberg competition, energy efficiency

\section{Introduction}

In the past various national and international policies have been implemented in EU countries in order to improve energy efficiency (Oikonomou and Patel 2004). A relatively new policy instrument is White Certificates (WhC), where energy saving targets are set for energy suppliers or distributors, which must implement energy efficiency measures among their clients. Energy suppliers or distributors, which overfulfill their targets, can sell their unused energy efficiency equivalents in the form of WhC to suppliers/distributors that have not reached their target. In the EU, only the 
UK, Italy and France have implemented WhC schemes, with different targets and design characteristics, and Poland is at the initial stage of their implementation.

Most economic studies on WhC deal with analysis of the instrument in a normative fully competitive environment (Bertoldi and Rezessy 2006; Bertoldi et al. 2005; EU SAVE "White and Green" project; EuroWhiteCert project; Farinelli et al. 2005; Guardiola et al. 2004; Harrison et al. 2005; International Energy Agency. 2006; Langniss and Praetorius 2006; Mundaca and Santi 2004; Oikonomou et al. 2008, Pagliano et al. 2003). Nevertheless, market trends demonstrate that a fully competitive market in the electricity supply industry in the EU at least is not the case so far. There is a trend in reconsolidating from horizontally integrated to vertical integration, let alone the introduction of large EU 15 electricity companies to the central-eastern EU markets.

To this end, decisions of electricity companies depend on the concentration of market power. Such is the oligopoly case in most countries, where larger companies can influence the market price and quantity and the remaining players adapt their strategies (for detailed strategies in oligopolistic environment see Green 2004, Maiorano et al 1999, and Nilsson 2005). Introducing WhC can perplex such decisions, because market conditions affect substantially the overall effectiveness of the WhC scheme. The purpose of this paper is to indentify an electricity supplier's behaviour in an oligopolistic market when participating in a WhC scheme.

In section 2 we present the business behaviour of a typical electricity supplier when facing an obligation of WhC. Section 3 deals with an oligopolistic market of electricity suppliers under a WhC scheme. In section 4 we apply our theoretical model to real data 
from electricity distributors in Italy in order to test our theoretical model and we conclude in section 5 .

\section{Electricity suppliers with White Certificates}

In this section we start by considering a single supplier firm problem acting in two markets: the electricity market and the white certificates market. Electricity suppliers sell purchased electricity to end-users (households, industry and tertiary sector). Sale of electricity includes metering, billing, marketing, and can be wholesale (large users) or retail (individual users) (Harris 2006, Steiner, 2000). Relevant labour and capital costs during this procedure can be aggregated to energy supply cost (represented as EURO/MWh) used for electricity sold. In the electricity market the price of electricity is a negative function of the amount of electricity supplied:

$P_{S}=a-b Q_{S}$, where $\mathrm{P}_{\mathrm{S}}$ is the electricity price, $\mathrm{Q}_{\mathrm{S}}$ is the total amount of electricity supplied in the market, $\mathrm{a}$ and $\mathrm{b}$ are parameters. Parameter a collects the effect of any exogenous variables that may shift the demand function. It also incorporates the effect of income and taste as well as the characteristics of the stock of appliances. An increase in income affects positively the parameter a and shifts the demand relation upwards. On the contrary, a more efficient stock of appliances should shift downwards the demand function. Parameter b represents price sensitivity of consumers. It is the slope of the demand function: a steeper relation is associated to a more rigid demand ( $b$ is higher and demand is less price-sensitive), while a less sloped function represents a more elastic demand ( $\mathrm{b}$ is smaller and demand is more price-sensitive). 
Obligations in a WhC scheme are set upon electricity suppliers or distributors (e.g. in Italy), In fact, in order to avoid market distortions, policymakers can impose such obligations also on natural gas, fuel for domestic use and heat suppliers. Bertoldi et al (2005) and International Energy Agency (2006) present several variations in terms of design and targets set in WhC. As far as design is concerned, WhC can function in a simple form (i.e. suppliers fulfil their obligations, receive $\mathrm{WhC}$ and can trade them in a certificate market), or more complex, involving also financial mechanisms for stimulation of energy efficiency actions. A target allocation can be uniform (same for all suppliers) or individual. In both cases moreover a target can be absolute (i.e. fixed amount of energy savings) or relative to electricity sales (certain fixed proportion of sales). In the WhC market there is a similar negative relationship between the amount of energy efficiency actions and the price of certificates:

$P_{W}=d-f Q_{W}$, where the price of certificates $\mathrm{P}_{\mathrm{W}}$ is negatively related to the amount of certificates in the market $\mathrm{Q}_{\mathrm{w}}$, while $\mathrm{d}$ and $\mathrm{f}$ are parameters. Price of certificates reflects the marginal costs of energy efficiency projects in the exogenous competitive market of energy efficiency, while amount of certificates are translated in energy saved (or in numbers of energy efficiency interventions, based on a linear relation like $1 \mathrm{WhC}=1$ toe saved). As in the demand function for electricity, parameter $\mathrm{d}$ collects all those exogenous factors that may shift demand. For example income, taste, but also legal requirements may enter parameter $d$. Parameter $f$ is a measure of price sensitivity and as above, given the slope of the demand function, we can obtain information about the size of the elasticity of demand (when $\mathrm{d}$ is higher, demand is rigid while when $\mathrm{d}$ is smaller demand is elastic). Each firm maximises its profits that come from the difference between the revenues and the costs on the two markets. Costs depend on the quantity of 
supplied energy and the amount of energy efficiency actions undertaken. The two markets are in principle separate. Each firm can make separate decision with respect to each product, given the characteristics of the demand, the cost structure, the technology features, legal requirements and the structure of the market (more or less competitive, depending on a number of issues, such as sunk costs and barriers to entry, regulation and liberalization, predatory practices). The mathematical analysis of electricity suppliers' behaviour can be found in Oikonomou et al (2009). Our intuition is that:

- Both markets can be considered as separate from the point of view of the consumers. This means that the demand function for energy does not depend on the prices of WhC or any other energy efficiency action. Similarly the price of WhC is not affected by energy prices. To a certain extent, this assumption is realistic given the well documented energy efficiency gap, i.e. the limited incentive of electricity price for undertaking energy efficiency actions.

- Both markets are linked when we take into account a firm's cost structure. By definition resources are scarce and we expect that total costs depend on both the quantity of electricity produced and the energy efficiency actions undertaken.

\section{Electricity suppliers in an oligopolistic market}

In this section we concentrate on the set of suppliers in an oligopolistic market. Implementing energy policies in such a market leads to various results based on the market power of participants (Davind 2005, Hasuike and Kanemoto 2005, Linares et al 2008, Mansur 2004). In Stackelberg competition, there is normally a larger electricity supplier and the residual demand is covered by the remaining suppliers. In this case, 
there is a leader and follower company, which aggregates the remaining suppliers, and prices are still set above marginal costs, but the leader sells more electricity and earns thus larger profits.

The leader company moves first, while the follower observes the choice of the leader and then it sets its quantity. The equilibrium of this game is a subgame perfect Nash equilibrium, where the leader can choose initially in which market to invest primarily, and this determines the residual demand for followers. An analytical mathematical formulation of these results can be retrieved by Oikonomou et al (2009). We argue that the Stackelberg model better represents reality, where one leader (ENEL, EDF, etc.) shares the market with a number of firms that have access to the same technology but must decide under the constraint of the first mover advantage of the leader, in comparison to a benchmark market, where firms simultaneously take their decisions. The main results we obtain can be summed up:

- The price of electricity is always higher under when all companies act simultaneously, leading to an increased incentive to act simultaneously in selling electricity. Similarly the price of $\mathrm{WhC}$ is higher, leading to an increased incentive to act simultaneously and promote energy efficiency, in comparison to a "wait and see" strategy.

- The existence of a market leader allows for larger quantities and lower prices in both markets. This results in an easier access to the electricity and energy efficiency market, where differentiated strategies can be applied, but at lower profit for all companies, in contrast to the situation where they act simultaneously. 
- From a consumers' point of view, more output is available at lower prices, enhancing total consumers' surplus. In other words energy efficiency actions triggered by a WhC scheme are less expensive and can stimulate consumers towards implementing relevant projects, overcoming thus substantial market barriers.

- Profits for the leader are high, while profits for the follower are lower. The consumer surplus enhancement is obtained at the expenses of the follower firm, which supplies less at lower prices. Nevertheless, depending on the cost margin of energy efficiency actions, the tradeoff of promoting energy efficiency projects (financed through the expectations of WhC prices) and supplying more electricity to cover the residual demand will determine the final strategy of suppliers. At the margin it could happen that followers are pushed out of the market.

- A larger player can undertake the lead of performing energy efficiency projects (because he has a bigger fragment of the market, more power to negotiate prices and to establish contracts with Energy Service Companies (ESCO's), as it is in fact in the market), and determine somehow the costs of $\mathrm{WhC} /$ projects that the others follow (since the market price signal of certificates will be leaded by the large company). So, in Stackelberg competition, the remaining demand is covered by small companies and the costs of energy efficiency for them is the cost of the large company.

\section{Effects of WhC in oligopoly: An Italian example}


In this section we make use of our example and apply it in a well established WhC scheme in Italy. In Italy, the obligations for energy efficiency projects are set to distributors of electricity and gas and became fully operational in 2005. The obligation is adapted every year on the basis of the quantity of electricity and gas distributed to consumers, thereby taking into account the total national objective in the previous year. At least $50 \%$ of the obligation must be achieved by energy savings or energy efficiency improvement. The rest can be obtained e.g. via fuel switching, given that quantifiable primary energy savings are achieved. Recently, this $50 \%$ constraint has been dropped altogether in order to stimulate more the energy efficiency market.

In so far, the Italian scheme has proven quite successful, almost 2 million toe are saved against a target of 1.1 million toe for the 2005-2007 period of implementation. From these savings, $78 \%$ are from electricity, $18 \%$ from natural gas and $4 \%$ from other fuels. Most of these projects belonged to the list of the predefined ones, where a deemed savings calculation exists with lower transaction costs. $63 \%$ of total savings were on electricity in the domestic sector, $21 \%$ for heating in the civil sector and $7 \%$ on electricity for public lighting (Pavan 2008). Furthermore, the market for Energy Service Companies was stimulated, as $75 \%$ of savings originated from such companies.

The Italian electricity distribution market is characterized by a strong oligopoly element, where one company satisfies the major bulk of electricity demand, while several others compete for the residual demand. Using a Herfindhal-Hischman index of electricity distribution in Italy, provides a clear indication of the concentration of the market for power operators in Italy subjected to WhC obligation. As a percentage of 
10.000 the period 2005-2007, the average is $79 \%$. In 2008 the index dropped to $24 \%$ because of the effects of the regulatory measures implemented at the end of December 2007 (AEEG, 2008)

In the WhC scheme, the same logic applies, where the leading company has received the largest part of the energy saving obligation. Figure 1 represents the actual official targets set for the year 2007 (AEEG, 2006) for electrical energy operators involved in the Italian WhC scheme. The targets are calculated accordingly to the energy distributed by each single operator in the previous year and thus can be used as a preliminary proxy of the market share: the presence of a very strong leader supports our natural preference for the Stackelberg competition model. The same condition has been also verified for 2008 targets (AEEG, 2007) data that show that the leader contributes for the $86,8 \%$ of the total.

$<<$ Insert Figure 1: Energy savings target for obliged operators (distributors) in the Italian WhC Scheme in 2007>>

Based on the energy saving potential of the dominant company towards clients, prices of WhC in the market are highly determined by the dominant company's behaviour. Figure 2 represents the actual volume weighted average prices of WhC (electricity) traded in Italy between the start of the electronic platform (as of 14th of march 2006) up to the end of 2007, in fact the mechanism at the end of 2007 has been characterized by relevant regulatory changes (Pavan, 2008) that affected the spot market prices in 2008 and that are not in the scope of the paper.

$<<$ Insert Figure 2: Spot prices for WhC traded in Italy $>>$ 
Linking up quantities of WhC (depicting energy saving projects and toe saved) and prices of these certificates, we can extract the inverse demand curve for energy efficiency in Italy. Figure 3 shows the official data (Alaimo, 2008) for the bilateral trades of WhC in the Italian energy efficiency scheme. Over the counter data have been preferred to spot data for this graph because they are more relevant i.e. the greater part of exchanges has taken place via bilateral trades in the timeframe shown.

$<<$ Insert Figure 3: Quantity and prices of WhC traded in Italy in the second and third quarter 2008. >>

In Stackelberg competition, present in Italy, the dominant company implemented a huge bulk of the 'low hanging fruits' at a relatively low cost (60-80 Euro/toe) and flooded the market with WhC, which gradually reduced their price. Other companies took a marginal part in the fringe of the WhC market and can purchase certificates at this lower price to cover their obligations. Furthermore, more expensive energy efficiency projects (90-100 Euro/toe) might be supplied in the market by the dominant company, which may finance these investments through selling certificates at a higher price, or more probably from own financial capacity, when scarcity of projects appears, while follower companies face a financial barrier towards more expensive interventions (which can generate more savings).

To this end, our main conclusions from theory are valid in the real market case in Italy. More specifically, in Stackelberg oligopoly, the market leader sold larger quantities of 
energy saving projects and thus $\mathrm{WhC}$ at lower prices, while it maintained its dominant position in the electricity market. The lower prices of such projects made them widely accessible in the Italian market and consumers responded positively to these prices, overcoming market barriers. There was no pressure hence in an oligopoly market from WhC prices towards electricity prices, contrary to the results presented by Oikonomou et al (2008) in a fully competitive market. Profits for the leader company from participating in both markets were much higher, since it could cover the entire spectre of costs of projects and supply the market with certificates at the whole range of costs, guaranteeing so high profits. Although no specific data for the other companies are present, still we can identify that if 'low hanging fruits' are supplied by market leader, the remaining residual demand consists of more expensive projects, which cannot be supplied easily by follower companies since they need to participate in the market with the same costs of a dominant larger company (that negotiates better prices of electricity, WhC, ESCO's and electricity contracts).

\section{Conclusions}

In this paper we demonstrate the effects of $\mathrm{WhC}$, as a relatively new policy instrument targeting at improving energy efficiency. The basic idea underlying this policy instrument is that energy saving targets are set for energy suppliers, which must fulfil these requirements by implementing energy efficiency measures among their clients within a specific time frame and these savings are acknowledged by WhC. This instrument is applied in a more realistic oligopolistic market, deviating from the existing literature, which is predominantly based on assumptions of full competition. 
We focus on electricity suppliers and their behaviour under the oligopoly paradigm, where one leader shares the market with a number of firms that have access to the same technology (from where it comes our assumption of identical cost structures) but have to take their decisions under the constraint of the first mover advantage of the leader. In general, the market leader supplies larger quantities and lower prices in both markets and this leads to higher consumer surplus in terms of electricity consumption and energy efficiency. Profits from the leader in both markets are higher than those of followers, which at the margin could lead to push out of smaller companies from the market.

Finally, we test these results in a real market case in Italy, where the market of electricity distribution is highly concentrated, and the WhC scheme has proven quite successful in terms of targets achievement. The leading company has received the largest part of the energy saving obligation, and sold larger quantities of energy saving projects and thus $\mathrm{WhC}$ at lower prices, while it maintained its dominant position in the electricity market. The lower prices of such projects made them widely accessible in the Italian market and consumers responded positively to these prices, overcoming market barriers.

\section{References}

AEEG - Autorità per l'energia elettrica e il gas (Regulatory Authority for Electricity and Gas), Decision no. 293/2006 on the Establishment of specific primary energy saving targets for 2007 for electricity and natural gas distributors 
subject to the obligatory requirements pursuant to the Ministerial Decrees of 20 July 2004. Downloadable at http://www.autorita.energia.it/docs/06/293-06.htm

AEEG - Autorità per l'energia elettrica e il gas (Regulatory Authority for Electricity and Gas), Decision no. EEN 1/2008 on the Establishment of specific primary energy saving targets for 2008 for electricity and natural gas distributors subject to the obligatory requirements pursuant to the Ministerial Decrees of 20 July 2004. Downloadable at http://www.autorita.energia.it/docs/08/00108een.htm

Bertoldi, P. and Rezessy, S. 2006. Tradable certificates for energy savings (White Certificates). European Commission Joint Research Center.

Bertoldi, P., Rezessy, S., Langniss, O. and Voogt, M. 2005. White, Green and Brown certificates: how to make the most of them? European Commission Joint Research Center.

Church, J. and Ware, R. 2000. Industrial Organization: A strategic approach. McGrawHill, Boston, MA.

David, M. 2005. Regulating a Polluting Oligopoly: Emission Tax or Voluntary Agreement?. Review of Development Economics 9(4): 514-529.

EU SAVE "White and Green" project. 2004. Intelligent Energy Europe Programme Downloadable at http://www.iiiee.lu.se/whiteandgreen.

EU SAVE “EuroWhiteCert project”. 2006. Intelligent Energy Europe Programme Downloadable at http://www.eurowhitecert.org.

Farinelli, U., Johansson, T., McCormick, K., Mundaca, L., Oikonomou, V., Örtenvik, M., Patel, M. and Santi, F. 2005. "White and Green”: Comparison of market- 
based instruments to promote energy efficiency. Journal of Cleaner Production 13(10-11): 1015-1026.

Green, R. 2004. Retail Competition and Electricity Contracts. Faculty of Economics (formerly DAE), Cambridge Working Papers in Economics, University of Cambridge.

Guardiola, M., Naturel, B., Perret, L. and Renaudie, G., 2004. Les Certificats d'Economie d'energie. Rapport pour l'atelier changement climatique, Ecole Nationale des Ponts et Chausses, France.

Harris, C. 2006. Electricity markets: Pricing, Structures and Economics. John Wiley \& Sons Ltd, West Sussex, UK.

Harrison, D., Sorrell, S., Radov, D., Klevnas, P. and Foss, A. 2005. Interactions of the EU ETS with Green and White Certificate Schemes. NERA Economic Consulting, London.

Hasuike, K. and Kanemoto, Y. 2005. Policy Evaluation for Oligopolistic Markets - A Case of Wholesale Electricity Market Discussion Papers. RIETI, Nomura Research Institute.

International Energy Agency. 2006.Market Mechanisms for White Certificates Trading - Task XIV Final Report. Implementing Agreement on Demand-Side Management Technologies and Programmes. A. Capozza (ed.), CESI Ricerca, Milano, Italy.

Langniss, O. and Praetorius, B., 2006. How much market do market-based instruments create? An analysis for the case of "white" certificates. Energy Policy 34(2): 200-211. 
Linares, P., Santos, F.J., Ventosa, M., and Luis, L. 2008. Incorporating oligopoly, CO2 emissions trading and green certificates into a power generation expansion model. Automatica (Journal of IFAC) 44(6): 1608-1620.

Maiorano, A., Song, Y. H. and Trovato, M. 1999. Imperfect competition: modelling and analysis of oligopoly electricity markets. Power Engineering Review, IEEE 19(5): 56-58.

Mansur, E. 2004. Environmental Regulation in Oligopoly Markets: A Study of Electricity Restructuring, POWER, University of California Energy Institute.

Mundaca, L. and Santi, F. 2004. Quantitative assessment of selected policy instruments using the Western European MARKAL model. Phase III of the EU SAVE "White and Green" project, International Institute for Industrial Environmental Economics, University of Lund.

Nilsson, M. 2005. Electric power oligopoly and suspicious minds--a critique of a recently approved merger. Energy Policy 33(15): 2023-2036.

Oikonomou, V., Jepma, C., Becchis, F., and Russolillo, D. 2008. White Certificates for energy efficiency improvement with energy taxes: A theoretical economic model. Energy Economics 30(6): 3044-3062.

Oikonomou, V., di Giacomo, M., Russolillo, D., and Becchis, F. 2009. White Certificates in an oligopoly market: Closer to reality?. EDREC Discussion Papers. Groningen [download at: http://www.rug.nl/edrec/onderzoek/PhDWorkshop/oikonomoueceee2009.pdf]

Pavan, M. 2008.Tradable energy efficiency certificates: the Italian experience. Energy Efficiency 1(4): 257-266. 
Pagliano, L., Alari, P. and Ruggieri, G. 2003. The Italian Energy saving obligation to gas and electricity distribution companies. ECEEE Summer Study. 


\section{Figures}

Figure 1: Energy savings target for obliged operators (distributors) in the Italian WhC

Scheme in 2007

\begin{tabular}{lrr} 
Operator & 2007 target (toe) & as \% of total \\
\hline Enel Distribuzione S.p.a., Roma & 341.933 & $88,7 \%$ \\
ACEA Distribuzione S.p.a, Roma & 15.596 & $4,0 \%$ \\
AEM Distribuzione Energia Elettrica S.p.a, Milano & 11.083 & $2,9 \%$ \\
ASM Brescia S.p.a., Brescia & 6.046 & $1,6 \%$ \\
AEM Torino Distribuzione S.p.a., Torino & 4.793 & $1,2 \%$ \\
Hera S.p.a, Bologna & 1.418 & $0,4 \%$ \\
Azienda Energetica S.p.a., Bolzano & 1.378 & $0,4 \%$ \\
Enì S.p.a., Parma & 1.308 & $0,3 \%$ \\
Acegas-Aps S.p.a, Trieste & 1.142 & $0,3 \%$ \\
Deval S.p.a., Aosta & 861 & $0,2 \%$ \\
\hline Total & 385.558 & $100 \%$
\end{tabular}

Figure 2: Spot prices for WhC traded in Italy

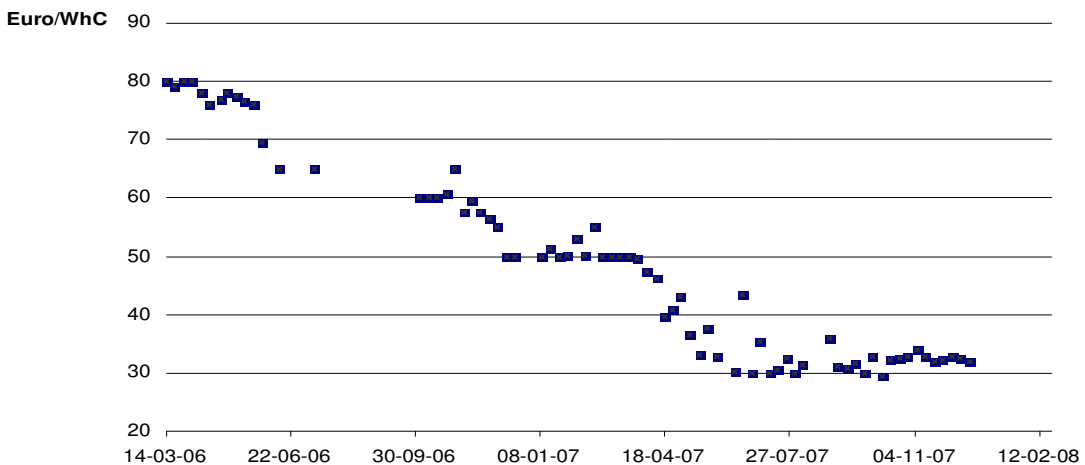

Figure 3: Quantity and prices of WhC traded in Italy in the second and third quarter

2008

Quantity (WhC)

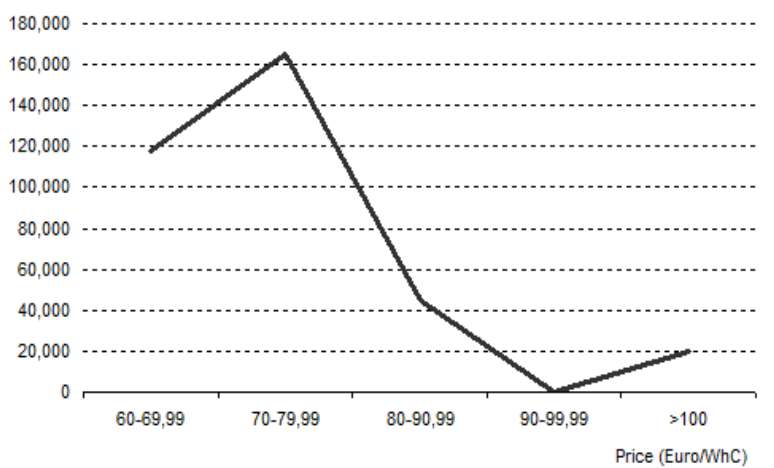

